\title{
TRADE UNIONS AND THE CHALLENGES OF EU ENLARGEMENT: 'THE KIND OF LAWS THE UNIONS OUGHT TO WANT'
}

\author{
ReBeCCA ZAHN*
}

\begin{abstract}
The recent EU enlargements in 2004 and 2007 have thrown up changed regulatory and opportunity structures for European trade unions, primarily as a consequence of an increase in the free movement of workers, services and establishment. In addition, the European enlargements came at a time when Member State governments were attempting to 'modernise' their labour and social security systems in order to combat the effects of an enlarged Europe within a globalised world economy. As a result, trade unions find themselves in a vulnerable position within their domestic legal systems and are required to reassess the type of functions that they can adopt at a national and European level in order to effectively respond to European enlargement. Against this background, this article considers the kind of laws the unions ought to want in order to effectively respond to the challenges facing them following the enlargements.
\end{abstract}

Keywords: European enlargement; labour law; migration; trade unions

\section{INTRODUCTION}

The European Union (EU) enlargements which occurred in 2004 and 2007 are unprecedented in scale in the EU's history. A majority of the ten Central and Eastern European countries which acceded in 2004 and 2007 combine weak domestic labour protection systems with a high proportion of workers and enterprises keen to take advantage of their free movement rights under the European Treaty. Combined with recent developments in the Court of Justice of the European Union's (CJEU) case law

Lecturer in Law, University of Strathclyde. I am grateful to Douglas Brodie, Kay Goodall and the participants of the BARSEA/INLACRIS Conference held in Cagliari on 17 and 18 December 2015 for helpful feedback on earlier drafts of this paper. I would like to thank Jeremias Prassl for organising the BARSEA network. The usual disclaimers apply. 
which created a difficult interface between national labour law and the provisions on free movement contained in the Treaty on the Functioning of the EU (TFEU), this has created a climate of fear amongst workers and trade unions in old Member States that their economic and social position is being threatened by those workers and enterprises who may avail themselves of their rights under the Treaty in order to engage in 'social dumping'. In addition, the European enlargements came at a time when old Member State governments were attempting to 'modernise' their labour and social security systems in order to combat the effects of an enlarged Europe within a globalised world economy, thereby threatening not only traditional trade union roles in the labour law system but undermining the purpose of collective labour law in regulating such a system. The increase in the free movement of workers following the European enlargements have exacerbated these pre-existing problems for trade unions. As a result, trade unions find themselves in a vulnerable position within their domestic legal systems and are required to reassess the type of functions that they can adopt at a national and European level in order to effectively respond to European enlargement.

This article proceeds on the basis that trade unions are necessary in order to preserve an equilibrium of power between workers and employers. It has long been recognised that unions are associated with a reduction in wage inequality, better workplace practices, improved health and safety, less labour turnover and increased productivity. ${ }^{1}$ In addition, trade unions can play an important role in ensuring the effective enforcement of legislation by giving workers 'the strength to insist on the maintenance of legal standards.' ${ }^{2}$ This is particularly relevant in the wake of the EU enlargements, where there is evidence that new Member State workers often struggle to enforce their rights at work. ${ }^{3}$

Against this background, this article considers, to borrow a title from Clive Jenkins and J.E. Mortimer, 'the kind of laws the unions ought to want'. ${ }^{4}$ In order to achieve this purpose, the article first provides a cursory introduction to the functions that trade unions adopt within their specific labour law systems and explains why these functions are under threat. In order to illustrate the challenges that trade unions are facing, this article draws on examples from the Austrian, German, Irish, and British industrial relations systems. Trade unions in these four countries are struggling to find ways to deal with the consequences of the recent European enlargements and, in particular, the arrival of new Member State workers. They are adopting similar functions within their respective national labour law systems. A second section of

$1 \quad$ See R. Freeman and J. Medoff, What Do Unions Do? (Basic Books 1984); S. Hayter (ed.), The Role of Collective Bargaining in the Global Economy (Edward Elgar/ILO 2011); and, L. Hayes and T. Novitz, Trade Unions and Economic Inequality (IER 2014).

2 P. Davies and M. Freedland (eds.), Kahn-Freund's Labour and the Law (3 ${ }^{\text {rd }}$ edn, Stevens 1983) 19.

3 See, for example, TUC Commission on Vulnerable Employment, Hard Work, Hidden Lives (TUC 2007) or DGB, Grenzenlos faire Mobilität (DGB 2012).

4 C. Jenkins, The Kind of Laws the Unions Ought to Want (Pergamon 1968). 
the article discusses why trade unions should consider law as a means of responding to the challenges of EU enlargement and what the obstacles are to such a strategy. A final section outlines the kind of laws trade unions ought to want. In doing so, the article moves beyond the current literature to provide a broader picture of necessary legislative changes which would assist trade unions in responding to the effects of European enlargement and to better integrate new Member State workers into their host labour market.

\section{TRADE UNION FUNCTIONS UNDER THREAT}

Keith Ewing identifies five principal functions of unions: a service function; a representation function; a regulatory function; a government function; and a public administration function. ${ }^{5}$ It should be noted at this point that the functions that Ewing identifies are based on a British point of view. Nonetheless, the categories which he identifies are sufficiently broad to encompass the main functions of trade unions within most European industrial relations systems. They thus form a useful starting point for an analysis of trade union roles and functions. ${ }^{6}$

The ambit of each of these functions is largely self-evident. According to Ewing, 'a service function means a function which involves the provision of services and benefits to members.'7 The meaning of the representation function is, again, obvious. All trade unions represent the interests of the worker at his place of work. The regulatory function 'acknowledges that trade unions are involved in a process of rule-making that extends beyond their members or the immediate colleagues of their members. ${ }^{8}$ Finally, the governmental and public administration functions of trade unions have two dimensions: first, trade unions represent 'the organised political representation of working people, both as a means of restraining the power of the State and a means of harnessing the power of the State'; ${ }^{9}$ secondly, trade unions engage 'in the process of government in the sense of being involved in the development, implementation and delivery of government policy. ${ }^{\text {'10 }}$

These traditional functions which characterise trade unions across all the countries at issue in this article are increasingly under threat from, inter alia, a

\footnotetext{
$5 \quad$ K.D. Ewing, 'The Function of Trade Unions' (2005) ILJ 1.

6 For an alternative analysis of trade unions in terms of the relationships which they form within a national system, see R. Gumbrell-McCormick and R. Hyman, Trade Unions in Western Europe: Hard Times, Hard Choices (OUP 2013). Gumbrell-McCormick and Hyman describe trade unions as being embedded in four main types of relationship: first, with their own members and constituents; second, with employers; third, with governments (which overlaps with Ewing's public administration function); and, fourth, with 'civil society'.

Ewing (n 5) 3.

Ibid 4.

Ibid 5.

Ibid.
} 
growing service sector; changing labour markets with increased emphasis on flexible and atypical forms of work; and trade union financial constraints that have come about as a result of decreasing membership levels. ${ }^{11}$ At the level of government policy, there have been attempts to 'modernise' labour and social security systems in order to combat the effects of an enlarged Europe within a globalised world economy and its associated phenomena such as 'social dumping.' ${ }^{2}$ The problems of changing economic and labour market conditions in an increasingly globalised world have been present in the EU for some time and have in some cases (particularly Ireland and the UK) been exacerbated by the recent financial crisis. ${ }^{13}$ However, the EU enlargements have added an extra layer of complexity to these pre-existing problems facing trade union functions. Most visibly, the enlargements have resulted in an increase in the free movement of workers ${ }^{14}$ which has created a number of challenges for trade unions.

First, there is a fear that new Member State workers may avail themselves of their free movement rights under EU Law to threaten the economic and social position of workers and trade unions in old Member States by engaging in 'social dumping'. Second, trade unions struggle to integrate new Member State workers into their structures and, as a result, new Member State workers frequently suffer from unfair employment practices. This creates tensions within the labour market between groups of workers which trade unions are badly placed to counter. Migration has always posed an inherent dilemma to trade unions, ${ }^{15}$ especially as opposing immigration 'contradict[s] notions of international solidarity.'16 Also, it may seem logical for trade unions to oppose immigration as migrant workers are perceived to pose a threat to indigenous workers who form the organisational base of the trade unions. However, 'once there are migrant workers in the country, it is essential to organise them - not only in their own interests, but also in the interests of the rest of the workers. ${ }^{17}$ This is particularly true of EU migrants, as restricting their entry - which is governed by EU law - is not a feasible option.

11 For an excellent comparative analysis and references to relevant literature, see GumbrellMcCormick and Hyman (n 6).

12 See, further, C. Barnard, 'Social dumping and the race to the bottom: some lessons for the European Union from Delaware?' (2000) ELR 57.

13 For an overview of some of the literature on the Eurozone crisis, see http://blogs.lse.ac.uk/ lsereviewofbooks/tag/euro-crisis/. The effect of the crisis on national labour law systems is explained by the ETUI in individual country reports here: https://www.etui.org/Publications2/WorkingPapers/The-crisis-and-national-labour-law-reforms-a-mapping-exercise.

14 See, further, G. Meardi, 'Union Immobility? Trade Unions and the Freedoms of Movement in the Enlarged EU' (2012) BJIR 99, 103-4.

15 See, further, S. Castles and G. Kosack, Migrant Workers and Class Structure in Western Europe (OUP 1973).

16 McGovern, Patrick, 'Immigration, Labour Markets and Employment Relations: Problems and Prospects' (2007) BJIR 217, 228.

17 Castles and Kosack (n 15) 128. 
Second, the EU's policy of 'europeanising' national labour law systems has had an effect on the environment within which trade unions act by creating a difficult interface between free movement law and national labour regulation thereby increasing the complex legal framework within which trade unions act. The debate surrounding the nature of 'europeanisation' ${ }^{18}$ has been raging in the EU for a number of years. It raises a variety of issues regarding the impact of the EU and its actions on the domestic politics and institutions of Member States and vice versa. 'Europeanisation' in the area of labour law has resulted in the progressive introduction of a social dimension to the EU. However, any attempts which have been made to introduce a comprehensive policy - largely under the banner of a so-called European Social Model - have been dependent on the effective accommodation of political interests. ${ }^{19}$ As a result, the European Social Model is patchy in its coverage of rights and has a curious character. Initially conceived of as a 'market-correcting' tool and then gradually widened through increased legislative competence so as to foster 'socio-economic integration', ${ }^{20}$ it never developed as an all-encompassing and comprehensive European social policy. Prior to the EU enlargements in 2004 and 2007, the lack of a comprehensive social dimension at EU level did not create major obstacles to the effective exercise of the free movement provisions contained in the Treaty. However, the particular characteristics of the new Member States' economic and institutional structures - on the one hand, favourable industrialisation legacies, skill structures and a stable institutional environment; ${ }^{21}$ and, on the other hand, low wage levels and collective agreement coverage as compared to Western Europe 22 - have resulted in an intensification of competition that had not occurred after the previous ${ }^{23}$ enlargements. At the same time, the CJEU's recent case law in the social sphere has created a difficult interface between social rights and EU

$18 \quad$ 'Europeanisation' has been defined broadly in the academic literature by various writers. For one of the earliest definitions of the term see R. Ladrech, 'Europeanisation of Domestic Politics and Institutions: The Case of France' (1994) JCMS 69, 69. Other authors who have examined the meaning of europeanisation include T.A. Börzel and T. Risse, 'When Europe hits home: Europeanisation and Domestic Change' (2000) European Integration Online Papers 4; J. Olsen, 'The Many Faces of Europeanisation' (2002) JCMS 921; K. Featherstone and C.M. Radaelli (eds.), The Politics of Europeanisation (OUP 2003); and, R. Ladrech, Europeanization and National Politics (Palgrave 2010).

19 See Ulrich Weinstock, 'Europäische Sozialunion - historische Erfahrungen und Perspektiven' in Wolfgang Däubler (ed.), Sozialstaat EG? Die andere Dimension des Binnenmarktes (Bertelsmann 1989).

20 D. Schiek, Economic and Social Integration: The Challenge for EU Constitutional Law (Edward Elgar 2012) 50.

21 D. Bohle and B. Greskovits, 'The state, internationalization, and capitalist diversity in Eastern Europe' (2007) Competition and Change 89.

22 Colin Crouch and Sabina Avdagic, 'Organized economic interests: diversity and change in an enlarged Europe' in Paul M. Heywood, Erik Jones, Martin Rhodes and Ulrich Sedelmeier, Developments in European Politics (Palgrave 2006).

23 For example, during the 'southern' accessions: Greece (1981), Spain and Portugal (1986). See also D. Vaughan-Whitehead, EU Enlargement versus Social Europe? The uncertain future of the European Social Model (Edward Elgar 2003). 
free movement law ${ }^{24}$ which has not been adequately resolved by the EU legislative institutions. ${ }^{25}$ Taken together, the incomplete nature of the EU's social dimension coupled with the CJEU's recent case law have thrown up not only changed regulatory structures but also opportunities for European trade unions. ${ }^{26}$ These changes at a European level have occurred primarily as a consequence of an increase in the free movement of workers, services and establishment. As a result, trade unions find themselves in a vulnerable position within their domestic legal systems and are required to reassess the functions that they can adopt at a national and European level in order to effectively respond to European enlargement, primarily by facilitating the integration of new Member State workers into their host labour markets. This article argues that, as part of this process, trade unions should consider legislative changes which would help them to better respond to the changing environment existing at a national and European level following the recent enlargements. A successful response to the effects of European enlargement could help trade unions to define a new role for themselves in their national labour law systems to ensure their continued relevance as institutions.

\section{THE ARGUMENT FOR LAW - WHY AND HOW?}

Jenkins and Mortimer, writing in 1968 about British 'collective laissez-faire', 27 make a convincing case in their book The kind of laws the unions ought to $w_{n} t^{28}$ for a legal framework which not only protects trade union rights but also establishes minimum labour standards; such laws are not designed to replace voluntary action by trade unions but to complement it by creating a framework within which effective collective bargaining can take place. Jenkins and Mortimer argue that sole reliance on industrial strength is both harmful to workers' interests and results in 'serious defects [...] in relation to trade union rights. ${ }^{29}$ This has become particularly obvious in the wake of the European enlargements in Austria, Germany, Ireland and the UK, where trade unions have struggled effectively to enforce labour rights of both national workers and

$24 \quad$ Case C-438/05 The International Transport Workers' Federation and The Finnish Seamen's Union $v$ Viking Line ABP and OÜ Viking Line Eesti [2007] ECR I-10779; C-341/05 Laval un Partneri Ltd v Svenska Byggnadsarbetareförbundet, Svenska Byggnadsarbetareförbundets avd. 1, Byggettan, Svenska Elektrikerförbundet [2007] ECR I-11767; Case C-346/06 Dirk Rüffert, in his capacity as liquidator of the assets of Objekt und Bauregie GmbH \& Co. KG v Land Niedersachsen [2008] ECR I-1989. For a small selection of literature see the website of the European Trade Union Institute (www.etui.org/Topics/ Social-dialogue-collective-bargaining/Social-legislation/The-interpretation-by-the-EuropeanCourt-of-Justice/Reaction-to-the-judgements/Articles-in-academic-literature-on-the-judgements). See, further, The Adoptive Parents, 'The Life of a Death Foretold: The Proposal for a Monti II Regulation' in Mark Freedland and Jeremias Prassl, Viking, Laval and Beyond (Hart 2014).

See also Meardi (n 14).

See, further, Otto Kahn-Freund, 'Labour Law' in Morris Ginsberg (ed.), Law and Opinion in England in the 20 $0^{\text {th }}$ Century( Stevens 1959).

Jenkins (n 4).

Ibid vii. 
migrants and, as a result, to react to the consequences of the europeanisation of their national labour law systems by relying solely on traditional trade union functions.

Jenkins' and Mortimer's approach harks back to Sydney and Beatrice Webbs' analysis which advocated multiple methods of trade unionism: mutual insurance, collective bargaining and 'legal enactment' (legislative change). ${ }^{30}$ According to the Webbs, the increasing power of industry would mean that 'the only available method of securing a Common Rule is Legal Enactment. '31 The alternative is 'Trade Union failure and decay'. ${ }^{32}$

The regulatory challenges facing trade unions following the EU enlargements make collective bargaining increasingly difficult. The 'powerful interests' described by the Webbs can now be found both at a national and European level, and threaten to undermine established national industrial relations systems. Legislative change provides an alternative method for trade unions which, if successful, could support primarily their representation and regulation functions. Thus, the principal purpose of legislative change must be 'to regulate, to support and to restrain the power of management and the power of organised labour'; ${ }^{33}$ it is instrumental in correcting the imbalance in bargaining power inherent within the employment relationship, ${ }^{34}$ and complements collective bargaining as a method of trade unionism. Historically, labour legislation has indirectly provided support for the effective functioning of collective bargaining in all countries at issue in this article. In Germany, labour legislation's purpose is understood as 'creating a framework for the autonomous regulation of terms and conditions of employment by the workers and employers'. ${ }^{35}$ In Austria, legislation was adopted which allowed trade unions and employers jointly to regulate the labour market without state interference. In both countries, trade unions and employers were also embedded in the economy more broadly by being granted power and influence which went beyond industrial relations narrowly defined. ${ }^{36}$ Social partnership in Ireland granted a similar role to trade unions whereby

\footnotetext{
$30 \quad$ S. Webb and B. Webb, Industrial Democracy (Longman, 1920).

31 Ibid, 554

32 Ibid.

33 Davies and Freedland (n 2) 15.

34 For an overview of the literature on labour law's purpose, see P. Davies and M. Freedland, Labour Law: Text and Materials (2nd edn., Weidenfeld and Nicholson 1984); S. Deakin and F. Wilkinson, The Law of the Labour Market: Industrialization, Employment, and Legal Evolution (OUP, 2005); H. Collins, 'Justifications and Techniques of Legal Regulation of the Employment Relation' in H. Collins, P. Davies and R. Rideout (eds.), Legal Regulation of the Employment Relation (Kluwer 2000); and, B. Hepple, 'Factors Influencing the Making of Labour Law' in G. Davidov and B. Langille (eds.), The Idea of Labour Law (OUP 2011). For a critique, see R. Dukes, The Labour Constitution: The Enduring Idea of Labour Law (OUP 2014) 92-122 and 194-221.

35 Dukes, ibid 8.

36 See, further, W. Streeck, 'Industrial Relations: From State Weakness as Strength to State Weakness as Weakness. Welfare Corporatism and the Private Use of the Public Interest' in S. Green and WE Paterson (eds.), Governance in Contemporary Germany: The Semi-Sovereign State Revisited (Cambridge 2005).
} 
the state provided a framework for collective bargaining to take place on a regular basis and on a broad range of topics. ${ }^{37}$ In the UK, the regulation of the employment relationship occurred under the umbrella of 'collective laissez-faire'. As Wedderburn points out:

Although it has always suited its detractors to paint it as a lawless jungle, collective laissez-faire involved not 'no law', but rather a particular type or quality of law, one which put a premium on protecting autonomous collective bargaining and which necessarily, demanded areas of liberty for trade unions. ${ }^{38}$

Within each legal system, legislative intervention - either through positive legal encouragement or through the creation by the State of an autonomous space for employers and trade unions - therefore provided the necessary framework within which trade unions could exercise their primary functions: to represent their members vis- $\grave{a}-$ vis the employer and, against that background, to engage in collective bargaining for the regulation of terms and conditions of work. The other functions exercised by trade unions complement this primary function. Thus, the service function, while relevant, can also be provided by other organisations which are either linked to the trade union movement - such as the Arbeiterkammer in Austria ${ }^{39}$ - or separate from it; the Migrant Rights Centre in Ireland ${ }^{40}$ being one example which has taken over much of the provision of advice to migrant workers from trade unions. The government function inter alia enables trade unions to secure necessary support for positive legislative developments.

Over the last twenty years, the vulnerability of trade union functions has become obvious across all four countries at issue in this article, albeit to varying degrees in each State. The UK stands out as a clear example of a system where reliance on industrial strength alone left trade unions vulnerable to unfavourable legal regulation in the 1980s which resulted in the eventual decline of trade union influence across a number of sectors. More recent examples of trade union vulnerability can, however, also be found

$37 \quad$ The Irish system of social partnership was founded on the conclusion of a succession of National Partnership Agreements between the Irish social partners between 1987 and 2009, which provided a framework for collective bargaining to take place on a regular basis and resulted in the conclusion of a national agreement fixing wage increases, but also dealing with other topics such as pensions and compliance with labour standards. See, further, W.K. Roche, 'Social Partnership in Ireland and New Social Pacts' (2007) 46(3) Industrial Relations 395.

38 K.W. Wedderburn, 'Change, struggle and ideology in British labour law' in K.W. Wedderburn, Labour Law and Freedom (Lawrence and Wishart 1995) 24.

39 The Arbeiterkammer (Labour Chamber) is a federal structure, established by public law with compulsory membership, which represents employees' interests. The Arbeiterkammer is unique to the Austrian labour law system and plays an important part in social partnership which is complementary to that of trade unions. See further M.E. Risak, Labour Law in Austria (Kluwer 2010).

The Migrant Rights Centre is a non-governmental organisation which offers an advisory service and participates in organising campaigns around relevant issues. It has a working relationship with a number of Irish trade unions and has taken on a strong advisory role in relation to migrant workers. 
in Ireland, Austria or Germany. Thus, the breakdown of social partnership ${ }^{41}$ - not anchored in law - in the wake of the economic crisis has deprived Irish trade unions of aspects of their regulatory function as well as their governmental function. In contrast, despite their aversion to legal intervention, trade unions in Austria and Germany seem to have recognised the increasing precariousness of their role within their respective labour law systems, and have used their governmental function in order to press for legislative change which can help to secure their relevance. The introduction of a minimum wage in Germany ${ }^{42}$ is one such example, as is the Austrian trade unions' lobbying for the recognition of social partnership within the Austrian Constitution. ${ }^{43}$ The changing regulatory and opportunity structures which have arisen following the recent EU enlargements have further challenged traditional trade union functions. It is therefore timely to consider legislative change as an alternative method of trade unionism. As the Webbs recognised, 'if Collective Bargaining, with its inevitable accompaniment of collective abstention from work and occasional stoppages of industry, is, by the judges' interpretation of the law, made impossible, or even costly and difficult, the whole weight of working-class opinion will certainly be thrown in favor of Legal Enactment.' ${ }^{\prime 4}$

How, then, should legislative change be achieved? One obstacle to legislative change is that trade unions must enjoy a significant measure of political strength ${ }^{45}$ which is variable across different countries. In Austria and Germany, the level of political involvement and positive labour legislation are dependent on the party in government at any one time. In Ireland, trade union political power depended on

41 The onset of the financial crisis had a dramatic impact on the system of social partnership and the locus of collective bargaining has shifted to the company level where trade unions are present in the workplace. See, further, M. Doherty, 'It must have been love ... but it's over now: the crisis and collapse of social partnership in Ireland' (2011) 17 Transfer 371.

42 There has been an intense political debate in Germany in recent years as to the benefits and disadvantages of a minimum wage. German trade unions initially had great difficulty in supporting the idea of a minimum wage as it implied that collective agreements were no longer sufficient to regulate industrial relations. It also meant that trade unions had to accept state involvement in the sphere of industrial relations; an area where regulation is usually left to the social partners and the courts. However, due to the decline in trade union strength through falling membership numbers and the increase in industries that are not covered by a collective agreement, German trade unions recognised the importance of a statutory minimum wage. A statutory minimum wage was adopted in Germany in April 2014 and came into effect in 2015. See, further, Mindestlohngesetz vom 11. August 2014 BGBI. I S. 1348 and M. Spielberger and A. Schilling, 'Das Gesetz zur Regelung eines allgemeinen Mindestlohns' (2014) 67(40) Neue Juristische Wochenschrift 2897.

43 The coalition government between the right-wing Freedom Party of Austria (FPÖ) and the centreright Austrian People's Party (ÖVP), in power between 2000 and 2007, overtly challenged social partnership which had no statutory basis. The realisation by the social partners of the precariousness of their role led to increased calls for legislative change in order to codify social partnership in the Austrian Constitution. Article 120a (paragraph 2) now acknowledges the role of the social partners. See, further, H. Obinger and E. Talos, Sozialstaat Österreich Zwischen Kontinuität und Umbau: Eine Bilanz der ÖVP/FPÖ/BZÖ Koalition (VS Verlag 2006).

$44 \quad$ Webb and Webb (n 30) xxxvi.

45 See E. Fraenkel, 'Die politische Bedeutung des Arbeitsrechts' in T. Ramm (ed.) Arbeitsrecht und Politik Quellentexte 1918-1933 (Luchterhand 1966) 249; and, Davies and Freedland (n 2) 52. 
the maintenance of the system of social partnership. Although British trade unions have long had strong institutionalised links with a political party, legislative changes introduced in 2014 to restrict trade union electoral activity ${ }^{46}$ coupled with changes to trade union involvement in the Labour Party ${ }^{47}$ threaten to severely restrict opportunities for engagement for trade unions with the political process. In order for trade unions to rely on legal enactment as an effective method, they should therefore focus on establishing and maintaining strong ties with political parties. As the Webbs have argued, trade unions 'would be strongly, and even permanently, drawn to any political leader, of whatever party, who shared their faith in the efficacy of [collective bargaining], and who convinced them that he had the technical knowledge, the will, and the Parliamentary power to carry into law such proposals for legal regulation as each trade from time to time definitely demanded. ${ }^{48}$

In order to ensure their continued relevance, therefore, trade unions cannot continue as they have done by focussing the majority of their attention at preserving the status quo. Instead, 'trade unions must be engaged politically in order to secure legislation that will enable them to challenge the power of the employer, as well as legislation that will directly regulate the conduct of the employer in its dealings with their members. ${ }^{49}$ The alternative threatens, in the long run, to undermine the purpose of a trade union and thereby to threaten their very existence. This begs the question what kind of laws the unions ought to want.

\section{THE KIND OF LAWS THE UNIONS OUGHT TO WANT}

In the increasing absence of government support and in order to maintain their status as 'a power countervailing management', ${ }^{50}$ Jenkins and Mortimer argue that trade unions need a legal framework of affirmative trade union rights along with laws which establish minimum standards for all workers. ${ }^{51}$ The precise content of such laws may vary from one legal system to another. However, a number of general suggestions can be made in light of the challenges facing trade unions following the recent European enlargements. First, trade unions need laws which guarantee the right to freedom of association. ${ }^{52}$ Second, trade unions require laws which establish a floor of rights for all workers. Such laws will enable trade unions to exercise their functions effectively in order to challenge the employer and to regulate the employer's conduct.

\footnotetext{
$46 \quad$ Transparency of Lobbying, Nonparty Campaigning and Trade Union Administration Act 2014.

47 See K. D. Ewing, 'The Importance of Trade Union Political Voice: Labour Law Meets Constitutional Law' in A. Bogg and T. Novitz, Voices at Work (OUP 2014).

Webb and Webb (n 30) 539.

Ewing (n 47) 277.

Davies and Freedland (n 2) 21.

Jenkins (n 4) vii.

Webb and Webb (n 30) 557-9.
} 
Due to the effects of europeanisation on national labour law systems, consideration must be given as to whether legislative demands should be made at an EU level in order to alleviate the negative consequences of europeanisation. Limited EU competence restricts the opportunities for legislative developments. Current legislative competences in the area of European social policy include not only the provisions contained in the EU Treaties which enable the EU institutions to act in order to facilitate the free movement of workers, but also Article 153(1) TFEU, which provides for the introduction of Directives on working conditions, information and consultation of workers, and equality at work between men and women. Article 153(4) TFEU allows Member States to maintain or introduce more stringent protective measures compatible with the Treaties. However, Article 153(5) expressly excludes competence over pay, the right of association and the right to strike. As Schiek points out, EU industrial relations constitute a 'multi-level system ${ }^{\prime 53}$ with the main regulatory authority and institutions residing at the national level. For trade unions, this gives rise to complex levels of interaction whereby some legislative demands can be targeted at the national and the EU level, whereas others should predominantly focus on the national level. The issue of competence is dealt with in relation to each section below.

\subsection{LEGAL FRAMEWORK WHICH GUARANTEES THE RIGHT TO FREEDOM OF ASSOCIATION}

The right of workers to organise in a trade union has long been recognised as a fundamental right. It is enshrined in Article 11 of the European Convention of Human Rights (ECHR), ${ }^{54}$ Articles 5 and 6 of the European Social Charter (ESC) ${ }^{55}$ and in Conventions 87 and 98 of the International Labour Organisation (ILO). ${ }^{56}$ The right has been recognised to include the right to collective bargaining and, more recently, the right to take collective action. ${ }^{57}$ States, as signatories to these international instruments, have a duty to uphold and protect these rights. Yet, achieving adequate protection of the right to freedom of association raises a conundrum for trade unions which is embodied in the ILO's Convention No. 87 on the Right to Organise: the law

53 D. Schiek, EU Social and Labour Rights and EU Internal Market Law, Study for the Empl Committee of the European Parliament (2015) 60.

54 For a detailed overview of the ECtHR's jurisprudence, see F. Dorssemont, K. Lörcher and I. Schömann (eds.), The European Convention on Human Rights and the Employment Relation (Hart, 2013).

55 See S. Evju, 'The European social Charter' in R Blanpain (ed.), The Council of Europe and the Social Challenges of the XXI Century (Kluwer, 2001).

56 These are the main relevant texts. Other ILO Conventions and Recommendations refer to the respective rights. See A. Odero and H. Guido, ILO Law on Freedom of Association: Standards and Procedures (ILO, 1995). See, further, T. Novitz, International and European Protection of the Right to Strike (OUP, 2003).

57 For an overview, see N. Busby and R. Zahn, 'Collective Labour Rights in EU and International Law: Consolidation, Reconciliation and Beyond?' in D. Brodie, N. Busby and R. Zahn (eds.), The Future Regulation of Work: New Concepts, New Paradigms (Palgrave 2016). 
should enable workers and employers to exercise their right to organise without, at the same time, interfering in that process. Similarly, ILO Convention No. 98 on the Right to Organise and Collective Bargaining protects the right to organise from interference, but also calls for the State to encourage and promote collective bargaining. States have responded to this conundrum by recognising the right to freedom of association as a fundamental right while, at the same time, placing restrictions on its exercise. Thus, freedom of association is recognised in the Austrian, Irish and German constitutions. In the UK, freedom of association has been enshrined in the Human Rights Act 1998. However, the protection of the right to freedom of association - and its corollaries, the right to collective bargaining and the right to take collective action - to the level required by the relevant international instruments is far from assured in all countries at issue in this article; in some cases as a result of national developments, and in all cases as a consequence of the CJEU's case law.

At a national level, the Trade Union Bill $2015^{58}$ in the UK and the lack of recognition procedures for the purposes of collective bargaining in Ireland ${ }^{59}$ stand out as primary examples of cases where the State is failing to adequately guarantee the right to freedom of association in breach of international obligations. In 2015, the ILO's Committee of Experts also criticised Germany's comprehensive ban on industrial action applicable to civil servants. ${ }^{60}$ In theory, therefore, the right to freedom of association is protected in all Member States at issue in this article by virtue of the international agreements which they have signed. However, implementation in practice is often lacking. At a national level, trade unions should therefore continue to seek laws which give practical effect to the rights enshrined in international agreements.

At the EU level, the CJEU's case law has placed severe restrictions on the exercise of the right to collective bargaining in cross-border cases where there is a clash with the freedom to provide services or the freedom of establishment. To counter this negative development, trade unions require laws which adequately protect the right to freedom of association (and its corollaries, the right to collective bargaining and collective action) at EU level. The EU's competence in the sphere of collective rights, particularly freedom of association, collective bargaining and collective action, is limited, and any protection takes place largely through their status as fundamental rights. Following the entry into force of the EU's Charter of Fundamental Rights (CFR) in 2009, protection of the rights to freedom of association, collective bargaining and collective action is guaranteed by Articles 12 and 28 CFR. However, the effectiveness of the provisions as individually enforceable rights will depend on the CJEU's interpretation.

58 See, further, M. Ford QC and T. Novitz, 'An Absence of Fairness... Restrictions on Industrial Action and Protest in the Trade Union Bill 2015’ (2015) ILJ 522. of Experts (CEACR), adopted 2014, published 104th ILC session (2015) on Convention No 98. 
The case law so far has not been promising, ${ }^{61}$ and it has been argued that the CJEU has effectively 'disembowelled'62 the rights of any effect at EU level. Therefore, at the EU level, enhanced protection of labour rights is evident in theory but not in practice. Although the CJEU's case law has progressively led to an acceptance of collective rights as general principles bolstered by the CFR's 'generous provision' ${ }^{63}$ for such rights, recent rulings ${ }^{64}$ by the Court fall far short of bestowing such rights with protected justiciable status and of guaranteeing the right to freedom of association to the level required by the ECHR, ESC and ILO Conventions. For EU Member States, this clash raises a dilemma over conflicting obligations owed at the EU and international levels while at the same time leaving a number of questions unanswered as to how the conflicting jurisprudence of the ECtHR and the CJEU is to be reconciled particularly in light of the EU's accession to the ECHR. ${ }^{65}$ The multi-level system which protects (or threatens) the right to freedom of association raises opportunities for trade unions to demand legislative protection of the right not only at a national level but also within the EU context. In particular, it is essential that the right to freedom of association is guaranteed for trade unions at EU level as a right which is neither subordinate to economic freedoms nor subject to proportionality requirements. ${ }^{66}$

There are a number of options for the right to freedom of association to be protected at EU level. First, trade unions could petition for protection of the right to strike through EU legislation. Proposals have already been developed on a Social Progress Protocol to be inserted into the Treaties. ${ }^{67}$ In addition, although Article 153 TFEU expressly excludes EU competence in respect of the right to freedom of association and the right to strike, this has not prevented the Union from using alternative legal bases to propose measures, albeit unsuccessfully to date, on the exercise of the right to strike in the past. ${ }^{68}$ Second, the CFR has the potential to add value by expanding

61 See Case C-271/08 Commission v Germany [2010] ECR I-7091 and the Viking and Laval jurisprudence. For an analysis see P. Syrpis, 'Reconciling Economic Freedoms and Social Rights The Potential of Commission v Germany (Case C-271/08, Judgment of 15 July 2010)' (2011) ILJ 222; C. Barnard and S. Deakin, 'European Labour Law after Laval' in MA Moreau (ed.), Before and After the Crisis (Elgar, 2011).

62 KD Ewing and J Hendy, 'The Dramatic Implications of Demir and Baykara' (2010) ILJ 2, 8.

63 See B Ryan, 'The Charter and Collective Labour Law' in T Hervey and J Kenner (eds.), Economic and Social Rights under the EU Charter of Fundamental Rights: A legal perspective (Hart, 2003).

64 Ibid (n 24).

65 See Opinion 2/13 of the CJEU, paras. 187-190.

66 The latter has been partly remedied in Case C-396/13 Sähköalojen ammattiliitto ry v Elektrobudowa Spółka Akcyjna, judgment of 12 February 2015.

67 For an overview of the discussion, see A. Bücker, 'A comprehensive Social Progress Protocol is needed more than ever' (2013) 4 ELLJ 4.

68 See the failed Monti II proposal COM(2012) 130 proposed under Article 352 TFEU. Article 352 TFEU allows the EU institutions to adopt legislation in areas where the Treaties do not provide the necessary powers in order to attain one of the objectives set out in the Treaties. The adoption of such legislation requires unanimity from the Council and consent of the European Parliament. National parliaments must also be given the opportunity to scrutinise the proposed legislation before its adoption. 
the reach of EU law and contributing to the discovery of new general principles. ${ }^{69}$ This is dependent on the CJEU's willingness to interpret the provisions of the CFR. By enhancing the CJEU's ability to draw on a range of provisions in the social field, the CFR provides new possibilities for the interpretation of existing labour rights. ${ }^{70}$ One obstacle to a broad interpretation of Article 28 CFR is likely to be the uncertainty as to whether the provisions contained within Chapter IV Solidarity (including Article 28) are 'rights' or 'principles.' ${ }^{71}$ However, increased formalisation of the relationship between EU and international law (particularly in light of the EU's accession to the ECHR) has profound consequences for labour standards in this respect. The distinction between 'rights', more commonly provided under supranational and domestic legal systems, and the 'principles' underpinning international standards, is dissolving. The prominence given to international provisions within the EU's acquis by the CFR and the EU's impending accession to the ECHR means that such distinctions are likely to become unsustainable so that principles which are enshrined within the international order will have to be given real credence in future judgments of the CJEU, one example being the wide interpretation given by the ECtHR to freedom of association under Article 11 ECHR. ${ }^{72}$ The consequences of this process would be a move towards recognition of freedom of association in line with international standards by the CJEU.

\subsection{MINIMUM LABOUR STANDARDS}

Trade unions struggle to effectively challenge employers' conduct in those sectors where trade union membership, and consequently collective bargaining rates and collective agreement coverage, is low. This includes, inter alia, the service and agricultural sectors which have a high proportion of new Member State workers and where a number of problems arise: new Member State workers struggle to enforce their rights; trade unions are not able to ensure that labour standards are being upheld; and, national workers are fearful that they are being undercut by new Member State workers receiving lower wages. ${ }^{73}$ The CJEU's decisions in Laval and Rüffert

$69 \quad$ K. Lenaerts, 'Exploring the Limits of the EU Charter of Fundamental Rights' (2012) 8 ECLR 375, 386. The arguments in this paragraph are further expanded in Busby and Zahn (n 57). However, the CJEU has also used the CFR as a basis to discover new rights such as the 'freedom to conduct a business' contained in Article 16 CFR. See further J. Prassl, 'Business Freedoms and Employment Rights in the European Union' (2015) CYELS 189.

70 N Busby and R Zahn, 'The EU and the ECHR: Collective and Non-discrimination Labour Rights at a Crossroad?' (2014) IJCLLIR 2.

71 The CFR does not distinguish between rights and principles. Where rights are clearly articulated, its text contains specific restrictions relating to their exercise. The revised Explanations to the Charter (OJ 2007 C 303) provide examples of 'principles', for example, Article 26 on the integration of persons with disabilities, but they also state that some articles may contain elements of rights and principles. See, further, C Barnard 'The EU Charter of Rights. Happy 10th Birthday', [2011] 24 EUSA Review 5, available: <https://eustudies.org/assets/files/eusa_review/winter2011.pdf >, 6 .

72 See, further, Schiek (n 53) 78-85.

$73 \quad$ Ibid n 3. 
have thrown a spotlight on these concerns in the case of posted workers. However, the issues of non-enforcement of labour standards in certain sectors, along with the fear of new Member State workers engaging in 'social dumping' (whether as posted workers or as free moving workers), were present well before the CJEU's judgments ${ }^{74}$ and have not been properly resolved since the CJEU handed down its decisions.

For trade unions, there are a number of options in responding to these developments. They can either establish a presence in these sectors through effective recruitment - a strategy that has only been partially successful in certain, very specific cases - or they can push for legal regulation to help them to challenge the employer's conduct in these areas. Such regulation would create the necessary space in which trade unions can represent workers and regulate the employment relationship. Positive legal regulation in this case can take two forms: either to lobby for a system whereby collective agreements can be declared universally applicable; or, to support legislation which establishes minimum labour standards. The former option is only feasible if there is indeed a representative collective agreement (and representative bodies to negotiate it) which can be declared universally applicable. This is often not the case in those sectors where trade unions struggle to establish a presence, so such legislation would only be of benefit for trade unions in those sectors where some regulation through collective bargaining already takes place. In these areas, the provision of a legal framework which enables collective agreements to be declared universally applicable could provide support for collective bargaining whereby the state delegates the task of regulating a particular sector to those parties who are most familiar with the sector: trade unions and employers.

In those sectors where this is not an option, trade unions should consider supporting the introduction of minimum labour standards. As Ewing argues:

If collective bargaining is to be a means of delivering a standard of social and economic security, the State has an obligation to make adequate provision for those excluded from the process, and to make provision also to deal with questions of social citizenship which may stand on its fringes, dealt with by some but not all collective agreements. This suggests the need for a comprehensive regulatory framework operating alongside collective bargaining, both underpinning and complementing the process. ${ }^{75}$

Cases like Laval illustrate the vulnerability of a system of industrial relations based, predominantly, on collective bargaining. Thus, it would be in trade unions' interests to support the introduction of comprehensive minimum labour standards, particularly for those sectors where unions struggle to establish a presence. Such legislation should provide for labour standards to be set in consultation with the social partners

\footnotetext{
74 See, for example, the Irish Ferries Dispute (T. Krings, 'Irish Ferries, Labour Migration and the Spectre of Displacement' in M. Corcoran and P. Share, Belongings: Shaping Identity in Modern Ireland (Institute of Public Administration 2008).

75 K. Ewing, 'Democratic Socialism and Labour Law' (1995) ILJ 24, 103.
} 
thereby giving trade unions a role to play in their regulation. In addition, trade unions should be given a role in supervising the enforcement of minimum labour standards. The potential role of trade unions as effective enforcers of labour standards was most visible in situations like the Irish Ferries Dispute in Ireland ${ }^{76}$ or the Lindsey Oil Refinery Dispute in the UK. ${ }^{77}$ There have also been some legislative attempts to remedy enforcement problems at a national level which were triggered by the increase in free movement following the recent EU enlargements. For example, in Austria, the Lohn- und Sozialdumpingbekämpfungsgeset $z^{78}$ attempts to prevent payment below collectively agreed terms and conditions. In the UK, trade unions successfully lobbied for the introduction of the Gangmasters (Licensing) Act 2004 which aims to regulate labour providers in certain industries which have a high proportion of migrant workers. In Ireland, the Industrial Relations (Amendment) Bill $2015^{79}$ proposes to allow trade unions and employers to apply to the Labour Court to undertake a review of pay/pensions/sick pay in terms of workers in a particular sector. The Labour Court can then make recommendations to the Minister for the making of an order in these areas which will have legal effect. Nonetheless, problems with enforcement of labour standards remain, and trade unions would benefit from laws which give them - as worker representatives - a role to play in enforcement.

At the Union level, there is a general lack of competence to regulate employment conditions. Directive 2014/54 ${ }^{80}$ aims to facilitate the free movement of workers, to increases the options for workers who make use of their rights to free movement to raise individual complaints, and establishes the obligation of Member States to provide some support for individual rights enforcement. However, trade union involvement is voluntary and the Directive therefore does little to combat the concerns over increased migration following the recent EU enlargements. Other EU legislative proposals, such as the Monti II Regulation, ${ }^{81}$ have ended in failure. EU level collective agreements are also not a viable alternative. Although Articles 154(3) and 155 TFEU allow for the conclusion of EU level collective agreements independently from EU legislation, management and labour at EU level generally respect the prerogative of national

\footnotetext{
$76 \quad$ Ibid $n 74$.

77 See, further, C. Barnard, “British Jobs for British Workers”: The Lindsey Oil Refinery Dispute and the Future of Local Labour Clauses in an Integrated EU Market' (2009) 38 ILJ 245; and R. Zahn, “"British Jobs for British workers": The problem of collective agreements in the UK' (2010) 55 Juridical Review 181. See also ACAS, Report of an Inquiry into the Circumstances Surrounding the Lindsey Oil Refinery Dispute, 16 February 2009 www.acas.org.uk/CHttpHandler.ashx?id=1019\&p=0.

78 BGBI I Nr. 2011/24. The law criminalises payment below collectively agreed terms and conditions.

79 An overview of the bill is available under www.djei.ie/press/2015/20150508.htm; the Bill can be accessed at www.oireachtas.ie/viewdoc.asp? DocID $=28887 \& \&$ CatID $=59$.

80 Directive 2014/54/EU of the European Parliament and of the Council on measures facilitating the exercise of rights conferred on workers in the context of freedom of movement for workers. The Directive seeks to increase awareness of the free movement rules amongst public and private employers in order to minimise discrimination of EU workers in host Member States. Ibid n 68 .
} 
social partners and limit themselves to the conclusion of framework agreements for autonomous implementation. ${ }^{82}$ There have been some instances of coordination of collective bargaining, ${ }^{83}$ but the main form of negotiation that takes place at EU level occurs through the social dialogue. ${ }^{84}$

Individual labour law systems are diverse and specific to a national tradition. This makes EU level legislation difficult to achieve and has led to inconsistencies in the process of europeanisation. In the current context where the EU is made up of 28 Member States and has limited competence in the labour law sphere, different social and labour rights must be regulated at different levels. This is also in line with the EU's principle of subsidiarity (Article 5(3) TEU). Thus, overarching, fundamental rights such as the right to freedom of association must be guaranteed not only at the national level but also at the EU level. By way of contrast, the regulation of labour standards should only be undertaken at EU level if this can be done successfully. If this is not the case, then the EU institutions should limit themselves to creating the necessary space either through legislative intervention or abstention, within which collective bargaining can take place at the EU or the national level. In the case of the former, this involves the strengthening of the social dialogue and the constructive involvement of the social partners in the development of social policy and in the development of best practice through the use of soft law mechanisms. In the latter case, whenever relevant EU legislation such as a Directive is adopted, this should make provision for the involvement of trade unions in its implementation thereby encouraging collective bargaining at a national level. Finally, the EU institutions could give support to the social partners to engage in transnational and/or EU level collective bargaining on feasible topics.

\section{CONCLUSION}

Trade unions across Europe are struggling to respond to the challenges that have arisen following the recent EU enlargements by relying solely on their traditional functions which centre around the encouragement of collective bargaining. However, collective bargaining is only one of the methods of trade unionism and it is therefore timely for trade unions to consider legislative change as an alternative and complementary method. Laws at national and EU level which secure the right to freedom of association and which provide for minimum labour standards for all works would enable trade unions to effectively challenge the employer and regulate the employer's conduct.

\footnotetext{
$82 \quad$ Schiek (n 72).

83 See J. Hoffmann and R. Hoffmann, 'Prospects for European industrial relations and trade unions in the midst of modernisation, Europeanisation and globalisation' (2009) Transfer 389; M. Keune and P. Marginson, 'Transnational Industrial Relations as Multi-Level Governance: Interdependencies in European Social Dialogue' (2013) BJIR 473; and, D. Schiek, 'Europäische Kollektivvereinbarungen' in W. Däubler, (ed.) Tarifvertragsgesetz. Kommentar (Nomos 2012). See, further, Articles 153, 154, 155 TFEU.
} 